\title{
しごき加エによる表面平滑化に関する研究*
}

\author{
河合望*1，堂田邦 明*2 \\ 秋山和 洋*3, 王 志 剛*1
}

\section{Research on Mirror Surface Finish by the Ironing Process}

\author{
Nozomu KAWAI, Kuniaki DOHDA, \\ Kazuhiro AKIYAMA, and Zhrgang Wang
}

\begin{abstract}
The object of this paper is to clarify the mechanism of mirror surface finishing by the ironing process. The mirror surface is needed for electrooptical parts such as optical drums, magnetic discs, etc., which are currently being finished by diamond turning lapping, etc. In the ironing process, the metal surface on the die-side becomes the rubbed surface $(\mathrm{Ra} \fallingdotseq 0.05 \mu \mathrm{m})$. In the case of applying high viscous oil it is rather inferior to a die surface ( $\mathrm{Ra} \fallingdotseq 0.006,0.011 \mu \mathrm{m}$ ) and when lower viscous oils are applied, galling often occurs. The metal surface on the punch-side nears a replica of the punch surface as the reduction increases under the dry conditions at the punch-metal interface. In this experiment, the metal surface was finished to $\mathrm{Ra}=0.004 \mu \mathrm{m}$ under dry conditions on the punch-side. high viscous oil on the die-side and $50 \%$ in the reduction.
\end{abstract}

Key Words: Plastic Forming, Tribology, Press Working, Ironing, Aluminum, Extra-fine Surface

\section{1. 緒言}

近年, 光学ドラム, 磁気ディスクなど電子光学機器 関連の部品に扔いて高い寸法精度と高度の鏡面が必要 とされている。従来，これらの部品の表面仕上げには ダイヤモンドバイトによる超精密切削, 研削, ラッピ ングなどが慣用されているが，これを塑性加工によっ て達成できれば，生産能率の著しい向上とコストの低 減が期待できる。

塑性加工では，材料表面は成形に伴って創成され， その性状は工具面との摩摖現象の結果としてつくりだ されるから，望性加工における材料表面平滑化には， 面圧，摩擦せん断応力，相対すべり量，介在する潤滑 敦，工具と素材の表面性状と両材質間の適合性など極 めて多くの因子が影響する，塑性加工における摩擦潤 滑機棈に関する研究は極めて多いが(1)，表面仕上げに 狙いをおいた研究は必ずしも多くない。アルミニウム 板の冷間圧延に放ける表面仕上げ(2)(3)，絞りーしごきに

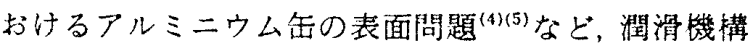

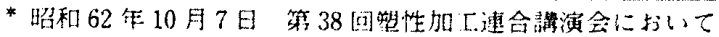
講演，愿醇受付 昭和 63 年 12 月 5 日

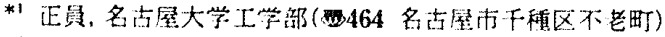

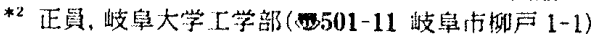

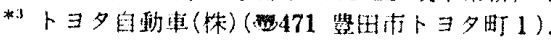

に関連して表面性状を検討した報告がみられる。平板 あるいは年体の塑性加工による鏡面創成には，原理的 には引技き，押出しなどいくつかの方法が洘えられる がここでは，まず平板のしごき加工をとりあげて検 討することとした。

上述の観点から，研究では，带板しごき加工装置 を用いて工業用純アルミニウム板(A 1100-0 材) にし ごき加工を加えると同時に，表面仕上げをも行い，製 品加工と鏡面化の同時達成に関する最適条件を明確に することを目的とする。

\section{2. 実験齐件}

$2 \cdot 1$ 実験装置 本実験に用いる带板しごき加工 装置は，既報のしごき形摩擦試験機(6)を改良したもの である。ここではその要点のみ説明する，図1に本装 置の加工原理を示す。带状素板(1)はポンチ(4)と一体で 上方に引き上ごられ，タイス(2)によってしごき加工が 加えられる。ダイス側では比較的大きな相対すべりを 伴いながらダイス面との摩擦を介して製品婊面が創成 されるが，ポンチ側では素板とポンチ表面との間に面 压が負荷された状態で比較的微小の相対す心゙りを生じ て表面が飤成される。本研究では，後述するようにポ ンチ側絮板面の鏡面化が容易なため，これを目的加工 
面とするが，タイス側素板面も比較模討の刘象とす る、しごき率の変更はガイド軸受(6)を左右に移動する ことにより行う。しごき加工中ダイス面に作用する垂 直力 $N_{D}$ および摩擦力 $F_{D}$ 仗測定体(3)によって分㒕測

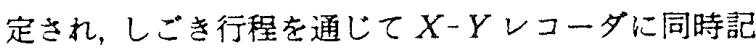
録される。

\section{$2 \cdot 2$ 実験条件 表面仕上げへの主要影響因子と} して，本実験では，しごき率，ポンチ面表面あらさ，潤 滑用をとりあげた。これらを含む主な加工条件を表 1 〜3にまとめて示す.しごき距離 $h$ は摩婑係数 $\mu$ 値が 定常値に達する $100 \mathrm{~mm}$ までとする。表1に示すよう に，しごき率 $R_{e}$ は $5 \%$ ～約 $50 \%$ までの範囲で種々変 更する，しごき速度は摩擦発熱による温度効果, 動圧 流体力学的効果をできるだけ小さくするため，1 $\mathrm{mm} / \mathrm{s}$ の低速で一定とした。ダイス材料には，ダイス 側の摩摖状態を変更するため合金工具鋼 SKD 11 およ び空化けい素 $\left(\mathrm{Si}_{3} \mathrm{~N}_{4}\right)$ の 2 種類を作製し，表面にはラッ ピング加工を施し，それぞれ $R_{a}=0.011,0.006 \mu \mathrm{m}$ 程 度まで仕上げた。ダイス出口には，わずかの丸昧はつ いているが, ベアリング部は特にはつけていない。ポ ンチ材料にはSKD 11 を用い，4種の表面あらさのも のを作製した. $R_{a}=0.354 \mu \mathrm{m}$ の最もあらい面はしごき 方向への研削によって作製し，他はラッピング条件の 変更により，仕上げあらさを調節した。最も平滑な面 牥超精密ラッピングにより $R_{a}=0.004 \mu \mathrm{m}$ 程度に仕上 げた。工具面には 1 試験ごとに再仕上げを施し，摩摖 面を常に同一条件に保つよう努めた。表 2 に, 供試素 板 A 1100 の機械的性質および化学成分を示す．板厚 $0.39 \mathrm{~mm}$ の軟質板から, 幅 $20 \mathrm{~mm}$, 艮さ $200 \mathrm{~mm}$ の 帯板を压延方向に採取し試験用素板とする。表 3 に供 試潤滑油性状を示す。粘度の異なるパラフィン系鉱油 3 種(St, P 4, P 3) および流動パラフィン 1 種(L 2) t

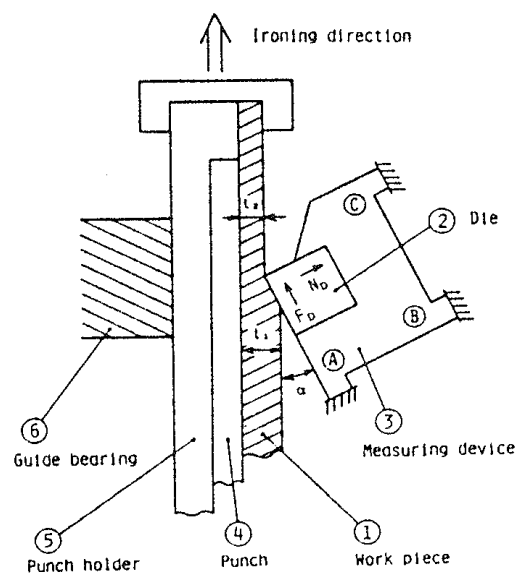

図 1 带板しごき加工原理
用いる。潤滑油㙰布条件を示すのに，以後たとえば，タ イス側洞滑油として St，ポンチ側潤滑油として L 2 を 使用した場合に洨(D)St-(P)L 2 と記す。

工具および素板摩擦面をアセトンで十分脱脂した後

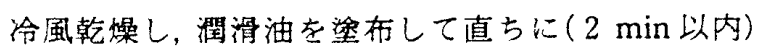
実験を行った。同一条件で3回以上の実験を繰返し行 い,すべての結果を検討の対象とした，実験室は温度 $20 \pm 1^{\circ} \mathrm{C}$, 湿度 $45 \pm 5 \%$ に空気調和した。

\section{3. 表面平滑化条件の検討}

表面平滑化への影響因子としてとりあげたしごき 率, ダイス面とポンチ面間の潤滑, およびポンチ面表 面あらさに関して以下順次検討を加える。

$3 \cdot 1$ しごき种の影響 図 2 は，表面あらさ $R_{a}=$ $0.02 \mu \mathrm{m}$ のポンチ(2)を用い, 潤滑条件を種々変更して, しごき率增加に伴う製品表面あらさの変化をみたもの である。表面あらさの測定には，触針式表面あらさ計 を用いて，しごき行程 $h=100 \mathrm{~mm}$ における素板面を，

表 1 しごき加工条件

\begin{tabular}{|c|c|c|}
\hline \multicolumn{2}{|l|}{ Die seni ancle $\alpha$} & $10^{\circ}$ \\
\hline \multicolumn{2}{|l|}{ troning reloctty } & $10 \mathrm{a} / \mathrm{s}$ \\
\hline \multicolumn{2}{|l|}{ Ironiag travol } & 10000 \\
\hline \multicolumn{2}{|l|}{ Ironing reductlon } & $5 \sim 50 \%$ \\
\hline \multirow{3}{*}{$\begin{array}{l}\text { Iool saterials } \\
\text { (Surface roughness) }\end{array}$} & \multirow{2}{*}{ Dio } & SKO11 ( $\left.R_{A}=0.011 \mu \mathrm{s}\right)$ \\
\hline & & $S t, H_{a}\left(R_{a}=0.006 \mu x\right)$ \\
\hline & Punch & 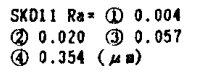 \\
\hline \multicolumn{2}{|l|}{ Roou temperatur: } & $20 \pm 1^{\circ} \mathrm{C}$ \\
\hline \multicolumn{2}{|l|}{ Roore hualdity } & $15 \pm 5 \%$ \\
\hline
\end{tabular}

表 2 試験用亲板 A 1100-0 材の性質と化学成分

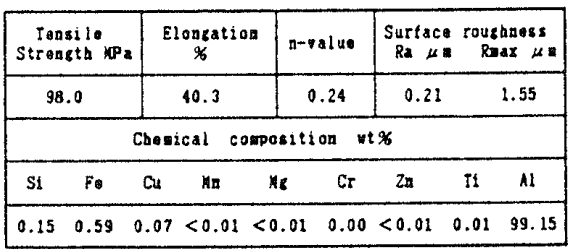

表 3 潤滑油性状

\begin{tabular}{|c|c|c|c|c|}
\hline Lubricant & L2 & P3 & 84 & st \\
\hline $\begin{array}{c}\text { Viscosity } \\
\left(10^{-0} \times / 5.20^{\circ} \mathrm{C}\right)\end{array}$ & 19.8 & 70.9 & $32:$ & 5119 \\
\hline Salphur vaigat \% & 0.00 & 0.15 & 0.25 & 0.95 \\
\hline 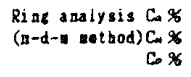 & $\begin{array}{l}0.0 \\
28.5 \\
71.5\end{array}$ & $\begin{array}{l}5.6 \\
26.8 \\
67.6\end{array}$ & $\begin{array}{l}7.0 \\
24.5 \\
68.5\end{array}$ & $\begin{array}{l}7.7 \\
26.7 \\
65.6\end{array}$ \\
\hline $\begin{array}{l}\text { heant molecular } \\
\text { Hestat }\end{array}$ & 305 & 393 & $\$ 19^{\circ}$ & 771 \\
\hline
\end{tabular}


しごき方向に垂直に測定した。

タイス側素板面で洨，ダイス側に高粘度油 St 潤滑 を行った場合には，工具材料，ポン千側罡滑が変わっ

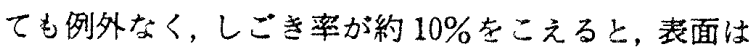
$R_{a} \fallingdotseq 0.05 \mu \mathrm{m}$ 程度の摖過傷面となる。これが本実稌籍 囲内では最良の表面仕上げとなったが，ダイス表面あ らさ $\left(R_{a}=0.006,0.011 \mu \mathrm{m}\right)$ に比へてかなり劣るもの である、既報(7)(8)の結果を参照すると，摩擦すべりが加 えられる表面では，工具面による擦過賃はきけがたく， 特別の手法を用いない限りこれ以上の仕上ごは困難と 思われる。ダイス側润滑油が P 3，L 2 と低粘度化す るとしごき率增加に伴い焼付きが発生し，表面むし

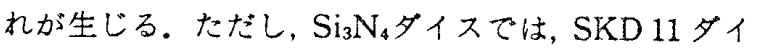
スに比較し焼付きは極めて少ない。すなわち，ダイス 面 L 2 潤滑の場合, SKD 11 ダイスでは激しい焼付き が発生し，しごき加工は全く不可能であったが, $\mathrm{Si}_{3} \mathrm{~N}_{4}$ ダイスを用いると部分的に焼付きが発生する程度とな る、いずれにしても，図2にみるように，燒付きが発生 すると，それによるむしれ部と擦過傷面が混在するた め表面あらさのばらつき声しく大きくなる。

ポンチ側素板面では，いずれの潤滑条件でも，しご き率の增加に伴い $R_{a}$ 注低下してゅく、ポンチ儧が Dry (無潤滑)あるい结低粘度油 P 3 の場合にも焼付き は全く発生せず, $R_{e}=20 \%$ になると，素板婊面あらさ はポンチ面の表面あらさ $R_{a}=0.020 \mu \mathrm{m}$ に接近する。 しかし、ポンチ側潤滑油が St と高粘度になると $R_{a}$

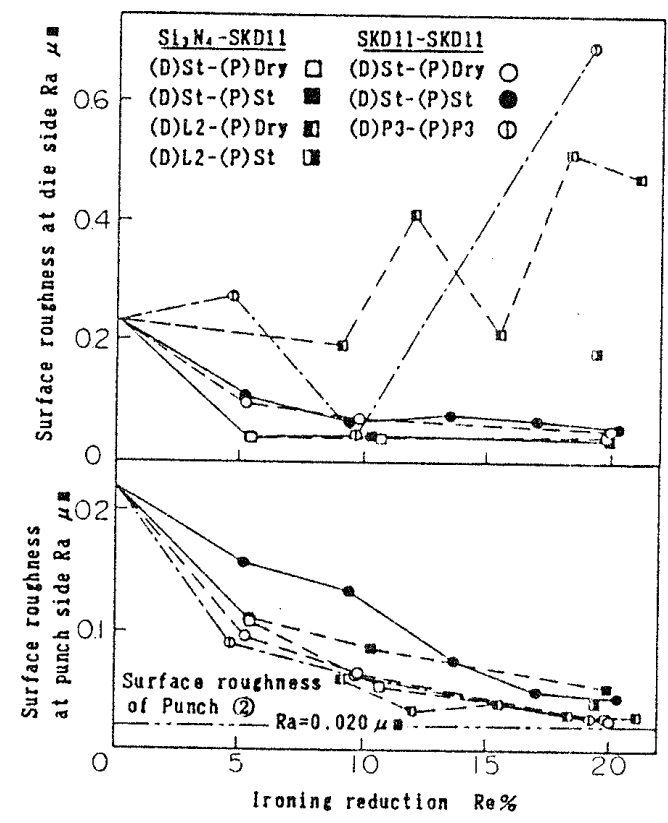

図 2 しごき染增加に伴う菜板表面あらさの变化 $(h=$ $100 \mathrm{~mm}$ )
注多少增加している。図11に後述するように，しごき 率增加统工具・素板面間の面压を低下きせるが，相対 すバり量を多少增加させる，上述の平滑化の機構に関 する理解は現在必ずしも十分でないが，素板の巨視的 塑性変形そのものが平滑化を助長するものとする説が 有力と考えている(9\%10).

図 3 おうよび図 4 にしごき率の增加に伴うポンチ側素 板表面性状変化の観察例および比較のためポンチ表面 あらさを示す。図 3 に示す(D)St-(P)St潤滑の場合。 図 3(b)から図 3(e) へとしごき率の增加に伴い平滑 化は進むが， $R_{e} \fallingdotseq 20 \%$ [図 3 (e)]によっても素板表面 に法圧延模様が残存し，ミクロプールによる凹部(黑 色はん点)がみられる。これは高粘度油による油膜厚さ 增お上び流動性劣化によるものと考えられる。一方， 図 4 に示す(D)St-(P) Dry 潤滑では, 図 4(a) 加ら図 4 (c) へとしごき率增加に伴い素板の圧延模様は次第 に消滅し，素板表面性状はポンチ表面性状に近づく。 しごき率の増加に伴い，工具面転写による平滑化が進 んでいるがわかる。

$3 \cdot 2$ しごき行程に伴う表面あらさ变化 図 5 は, しごき行程に伴うダイス側およびポンチ側素板表面あ らさの変化およびダイス面摩擦係数 $\mu$ 変化を示すも のである。前述の上うに，ダイス側では潤滑油が低粘 度化すると，焼付きが発生し，表面あらさ，片をに 增加し変動も大きい。一方ポンチ側では, ダイス側の

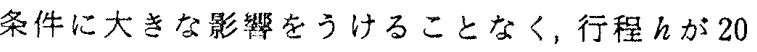
$\mathrm{mm}$ をこえるとRa性活定常化し，無潤滑あるいは 低粘度P 3 の場合にも焼付き山全く発生せず， $R_{a}$ は ほほポンチ面あらさ $0.02 \mu \mathrm{m}$ へと収束している。しか し, ダイス側 $\mu, R_{a}$ の変動が著しい(D) L 2 -(P) Dry の場合にはポンチ側表面あらさもわずかであるが変動 することがわかる。

$3 \cdot 3$ 潤滑条件の影響 図 6 は, $R_{e} \fallingdotseq 20 \%, h=$ $100 \mathrm{~mm}$ に打ける素板のダイス側,ポンチ側両面のあ らさを潤滑条件ごとに示したものである。ここに示き れた結果は，定性的に湔述の説明上り明らかであ る。最良のダイス側畒板面はダイス側潤滑油が高粘度 油 (St)の場合に出現しているが, $R_{a}=0.05 \mu \mathrm{m}$ 程度の 擦過傷面である。ポンチ側素板面が最良となる条件は， ポンチ側無潤滑，ダイス側潤滑高粘度油(St)の場合に 出現しポンチ表面あらさ $R_{a}=0.02 \mu \mathrm{m}$ に接近してい ることがわかる。この場合には， $R_{a}$ の変動範囲も著し く小さくなっている。

しかし，ポンチ側をSt潤消とした場合には，ダイ 又側の潤滑は低粘度化したほうが，ポンチ側素板面の $R_{a}$ は低下することがわかる.このことは，ダイス側で 


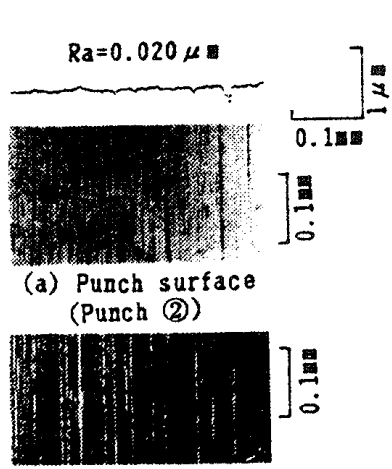

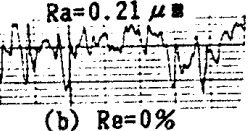

(b) $\mathrm{Re}=0 \%$

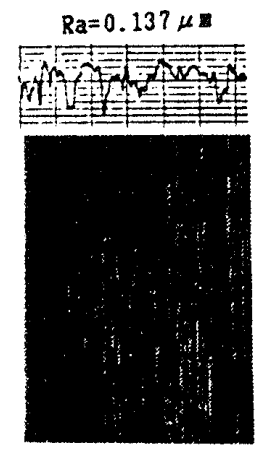

(d) $R e=10 \%$

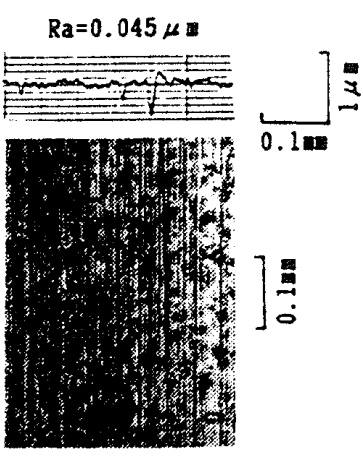

(e) $R e=20 \%$

(c) $\operatorname{Re}=5 \%$

Die : SKD11, Lubricant : (D)St-(P)St, $h=100 \mathrm{~mm}$

図 3 ポンチ側素板表面の性状変化（ポンチ側潤滑：St）

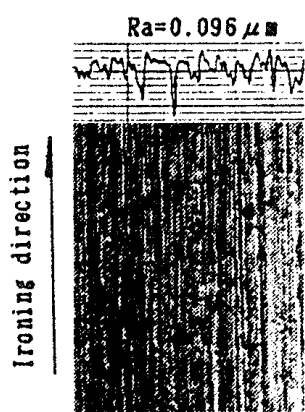

(a) $R e=5 \%$

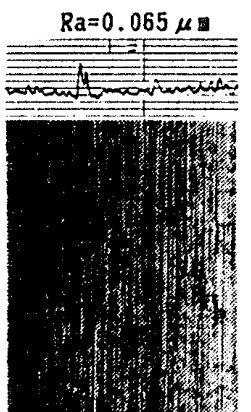

(b) $\operatorname{Re}=10 \%$

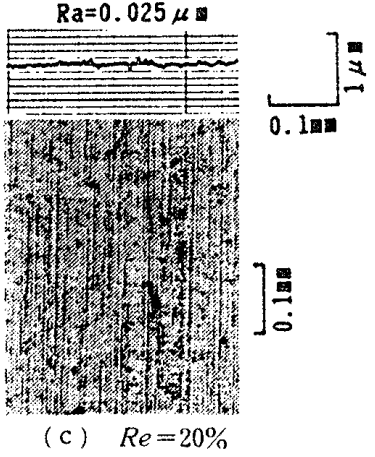

(c) $R e=20 \%$

Punch (2), Dis: SKD11, Lubricant: (D)St-(P)Dry, $h=100 \mathrm{~mm}$

図 4 ポンチ側素板表面の性状変化（ポンチ側潤滑：無潤滑）

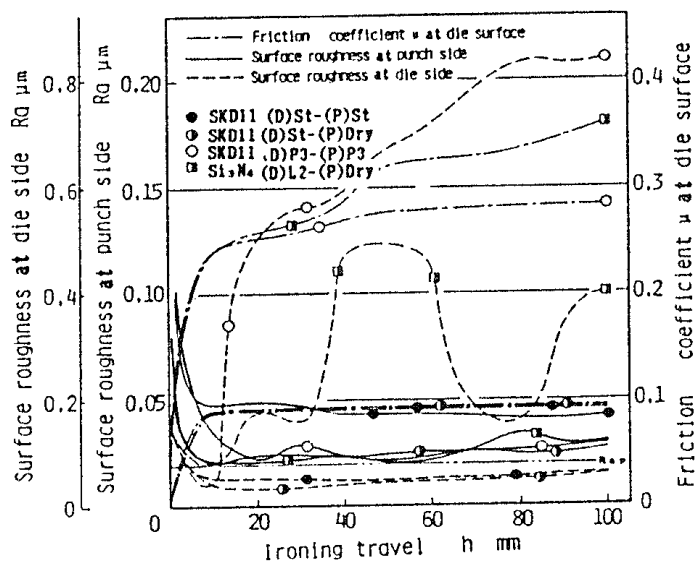

Punch (2); Die: SKO11; $\quad \operatorname{Re}=20 \%$

図 5 しごき行程に伴う素板表面あらさの変化

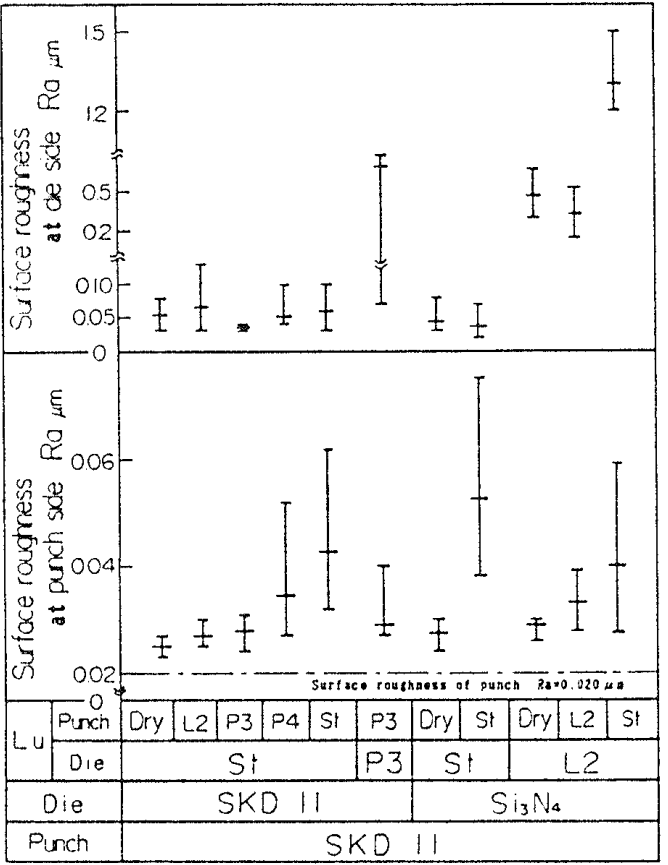

Punch (2): $h=100$ mas; $R e=20 \%$;

I : Fluc tuation ranse; Middle bar: Average value 図 6 潤滑条件としごき後素板婊面あらさ 
の高摩擦が接触面圧の上舁をもたらし，ポンチ側素板 面の平滑化を助長するものと考えうれる。るこて，(D) P 3-(P)P 3 潤滑でタイイス側に局部的な带状焼付きを 生じた場合についてダイス側とポンチ側の㵖板面の対 応を図 7 にって詳紐にみてみた。この寒験で洨、ダ イス側素板面中に生じた擦過㑑面 $\mathrm{A}^{\prime}$ 内に幅 $3 \sim 5$ $\mathrm{mm}$ 程度のむしれ面 $\mathrm{B}^{\prime}$ が混在した，そのとき，䯧面で あるポンチ側素板面には，ダイス側むしれ面に対応す る位置に目視による鏡面が出現した。図70上に示す あらさ曲線はダイス面側に切ける上述 2 種類の表面を 示し，下に纹，対応するポンチ側表面あら台曲線を示 す. $\mathrm{A}^{\prime}$ 部の寒側部分 $\mathrm{A} よ り \mathrm{~B}^{\prime}$ 部の集側部分 $\mathrm{B}$ のほう があらさが小きくなっていることがわかる，肉眼観察 によると，A部はやや白濁した摖過傷面であるが，B 面は光輝面となっている、図 8 に $\mathrm{A}$ 部および $\mathrm{B}$ 部の 相対負荷曲線を示す. A の白濁面よりBの光輝面が均 一な平滑面となっていることがわかる。この結果は, 鏡面化の一つの考え方を示唆するものとして興味樑 w.

\section{$3 \cdot 4$ 工具面表面あらさの影響 表面あらさの異}

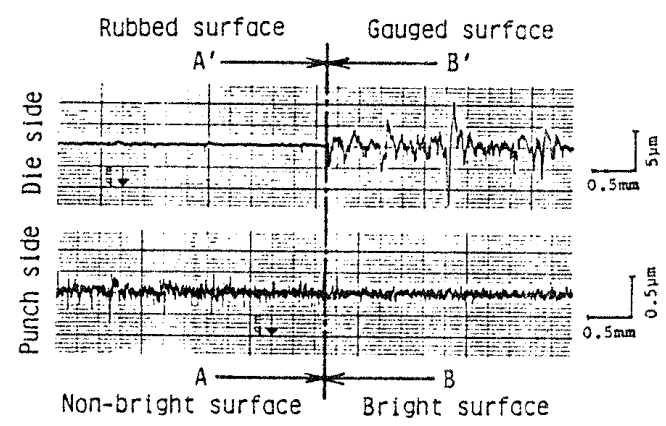

Punch (2. Die: SKD11, Lubricant: (D)P3-(P)P $3, R \theta=19.2 \%, h=100 \mathrm{sm}$

図 7 加工後の菜板表面性状 （ダイス側とポンチ側の比較）
なる4種類のポンチを用いた場合のしごき率とポンチ 側素板表面古らきの関保を図 9 に示す。就軸 $R_{a}$ は対 数目盛で示してある。ポンチ面を素板面よりあらくす ること法，必ずしも索板表面仕上げの向上にはつなが らないが，䎐写機構検討の参考とした。 $R_{a}=0.354 \mu \mathrm{m}$ とあらいポンチ(4)を用いた場合，しごき率の增加に伴 い菜板表面あらさ济工具面あらさに近づきしごき率 $R_{e}$ 約 $20 \%$ で工具面とほ浔同程度となっており，ポン 千側潤滑 Stと無潤滑の差注ほとんどない. 粗面化に より油の流出が容易になったためと考えられる。この 場合、工具面あらさは素板の表面あらさを $\left(R_{a}=0.21\right.$ $\mu \mathrm{m})$ より大きいため，素板面は転写により粗面化され ることになる。ポンチ(3)，(2)，(1)と表面あらさが低下すす ると，ポンチ面への転写性はポンチ側Dry(無潤滑)の 場合に良く，高粘度油 St の場合劣化し，介在する潤 滑油の影響が強まる。超精密表面創成のために, SKD 11 工具鋼の表面仕上げ状態としてはほほ限界に 近いポンチ(1) $\left(R_{a}=0.004 \mu \mathrm{m}\right)$ を蕉備した. (D) St-(P) Dry潤滑の場合には，特にしごき率を 41.3，49.1， $52 \%$ と順次高めたところ， $R_{e} \fallingdotseq 50 \%$ でほほ具面と同 程度の表面が得られた。

図 10 は, 転写性とポンチ表面あらさの関係を素板 とポンチの表面あらさの対数目盛表示で示したもので ある、ポンチ(4)および(3)とあらい場合には，しごき率 20\%で潤滑にほほ無関係に，ポンチ面と同程度かある いは多少とも良好な面が得られる。ポンチ面が平滑化 するに従い，転写性を高高しごき率が必要と なるが，超精密仕上げポンチ面(1)でもしごき率約 $50 \%$ でほほ完全な転写を達成し得ることがわかる。この結 果から，原理的に峙菜板表面は工具面と同程度の仕上 げまでしごき加工による転写によって創成されるもの と結論できる。しかし，しごきにより極薄板となるの で, 若干の曲がりの発生は避けられない。実用的には

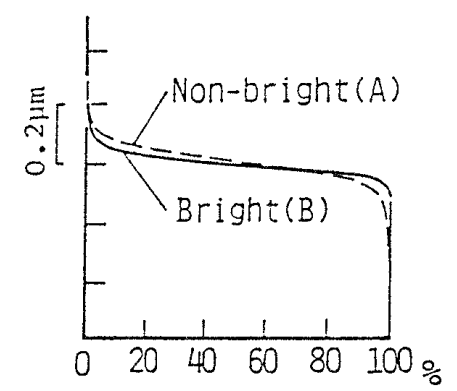

図 8 光輝面と白滥面の 相対偩荷曲線

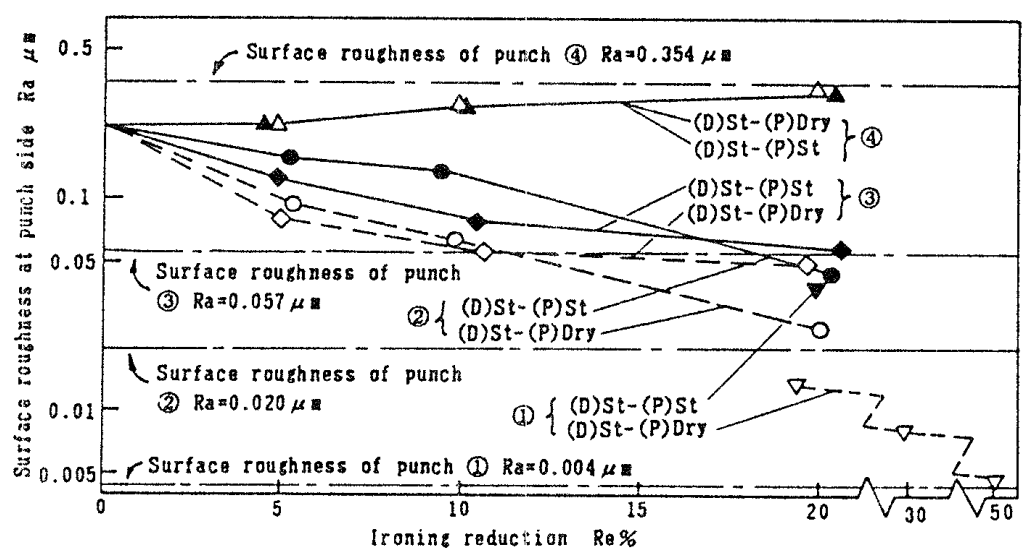

図 9 しごき率增加に伴う淁板表面あらさ変化 


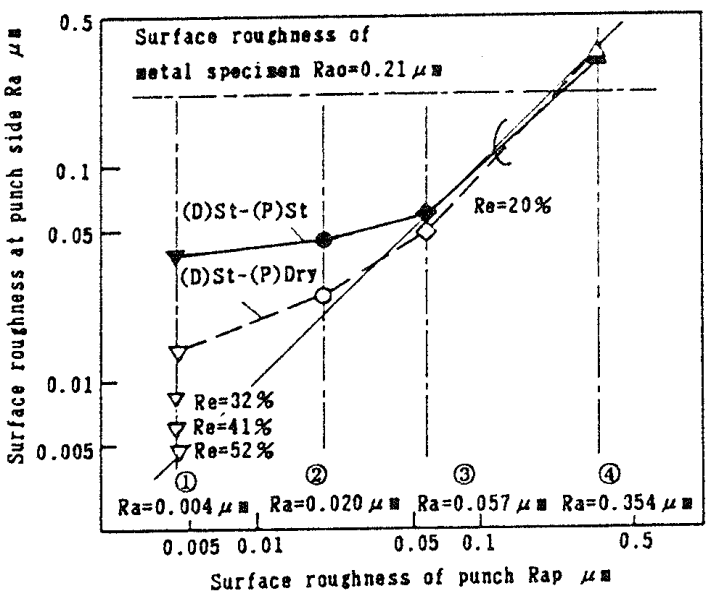

図 10 ポンチ面あらさとポンチ側㮦板表面あらさの関係

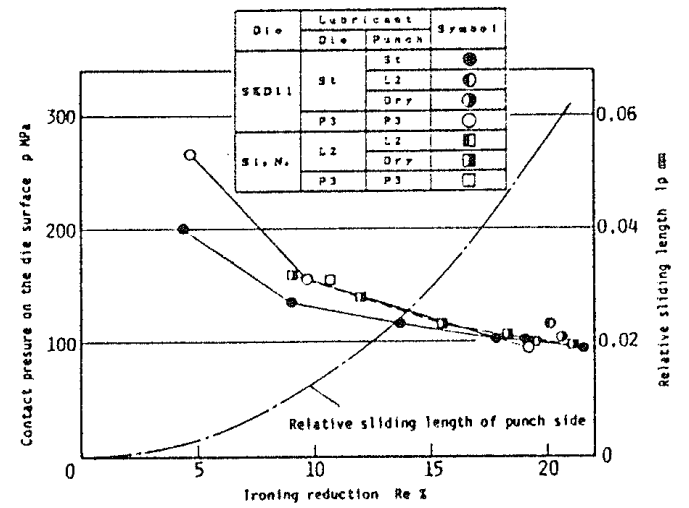

図11しごき率とダイス接触面平均面生, ポンチ側相対すべり僐の関係

ある程度剛な物体に接着して利用するような方法を考 える必要がある。

\section{4. 転 写 性}

前述のように，しごき率を高めると転写性が高めら れるが，その理由を若干考察してみたい。

図 11 は，しごき率とポンチ側相対すべり量 $1_{p} お よ$ びダイス面で測定された平均面圧 $p$ 関係を示すも のである。ここに，1pは菜板がダイスに入ってから出 るまでにポンチ面との間に生ずる相対すべり量で，平 行変形を仮定した計算值である。相対すべり量はしご き率が $20 \%$ と高まっても，0.055 mm 程度と微小であ る。しごき率増加に伴い面圧減少, 相対すべり草の増 加が生じ，それぞれ 3 因子が表面平滑化に影響するも のと思われるが，本実験条件下では，これらを独立に は制御し難い。3因子の分離検討は将来の課題とし， ここでは，ポンチ側素板表面あらさへの影䅨因子とし

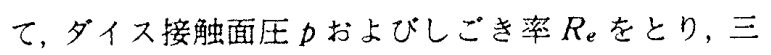

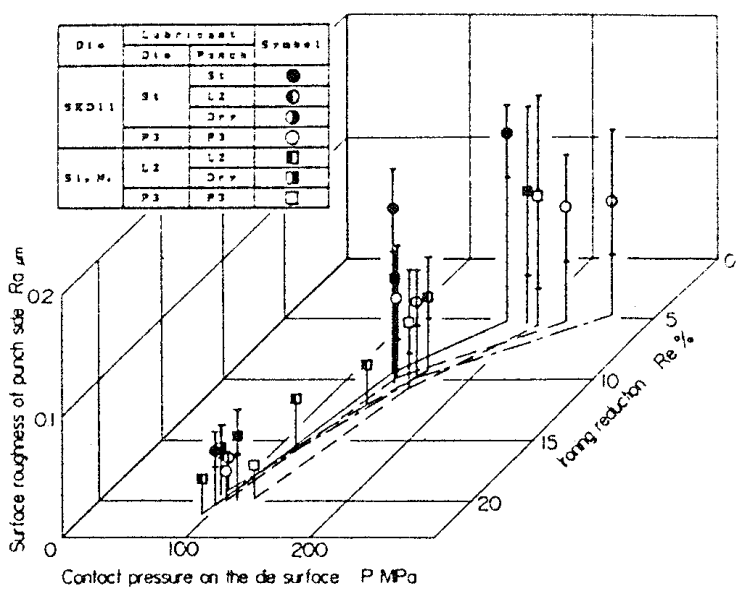

図 12 精密表面創成条件の三次元表示

次元表示したものが図 12 である. $R_{e}$ が大きいほど， またかが大きいほど平滑化が達成されることがわか る.

\section{5. 結咅}

しごき加工による表面平滑化条件の検討を行った結 果, 次のような結論を得た。ダイス側素板面では，タイ ス面との摩擦すべりによって表面が創成されるが，低 粘度油潤滑適用時には焼付きによる表面むしれが生 し，高粘度油潤滑ではおおむね擦過傷面となり $R_{a} \fallingdotseq$ $0.05 \mu \mathrm{m}$ 程度の表面仕上げがえられる。これはダイス 面に比べかなり劣るものである。ポンチ側素板面では, ポンチ面への転写によって表面が創成される. ポンチ 面・素板面間をDry(無潤滑)とししごき率を高めても， 焼付きは全く発生せず，転写性は著しく高まる。ポン 千面 $R_{a}=0.020 \mu \mathrm{m}$ の場合には，しごき率を $20 \%$ 程度 まで高めるとほぼ完全な転写画がえられる，本実験に おいて可能な限り超精密仕上げを施したポンチ面 $R_{a}$ $=0.004 \mu \mathrm{m}$ ではポンチ側 Dry（無潤滑）でしごき率を $50 \%$ 程度まで高めるとほぼ完全な転写面がえられる。 結局，しごき加工に伴う工具面転写を利用する表面仕 上げでは，しごき率を高めれば，工具面と同程度の表 面仕上げが可能と結論される。

\section{文献}

(1) 河含 - 堂国, 㚙性上加工. 25-285(1984)，861.

（2）水野・松源・木村。譏誌 71-595(1968)，1037.

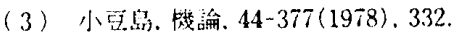

（4）村田・高淿，軽金低，33-1(1983)，16.

(5) Knepp. J. E., Lubr. Eng. 40-9(1984). 554.

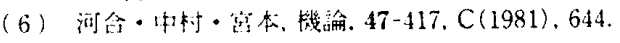

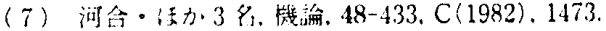

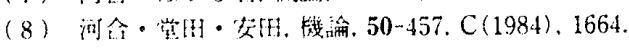

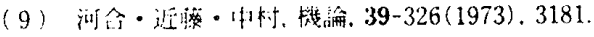

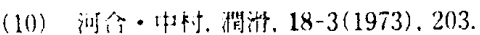

